\title{
The effects of lucerne hay particle size on chewing activity and rumen fermentation in dry cows ${ }^{*}$
}

\author{
T. Sun, S.L. Li ${ }^{1}$, M. He and Z.J. Cao \\ National Key Laboratory of Animal Nutrition, College of Animal Science and Technology, \\ China Agricultural University \\ Beijing 100094, P.R. China
}

\begin{abstract}
Three cannulated, multiparous dry cows were randomly assigned to a $3 \times 3$ Latin square experiment to evaluate the effects of different lucerne hay particle size on eating behaviour, chewing activity, and rumen fermentation based on measurements of the Penn State Particle Separator. During each of the 21-d periods, animals were offered one of three total mixed rations, which were chemically identical but included lucerne hay of different length $(2,4,8 \mathrm{~cm})$. Results showed that increasing lucerne hay particle size decreased intake of DM and NDF, increased chewing activities, rumen $\mathrm{pH}$ and ammonia concentration, and decreased the concentration of VFA.
\end{abstract}

KEY WORDS: lucerne hay, chop length, chewing behaviour, rumen, dry cows

\section{INTRODUCTION}

The concept of effective fibre was created to amalgamate the chemical characteristics and particle size of the forage, and to quantify its value to rumen function (Mertens, 1997). The ability to routinely measure ration particle size has been difficult until the introduction of The Penn State Particle Separator (PSPS). PSPS is a quick and effective tool to estimate forage or total mixed ration (TMR) particle size (Kononoff and Heinrichs, 2003).

Although a lot of studies have been conducted in recent years to determine the effects of dietary particle size on feed intake, chewing time and rumen $\mathrm{pH}$, data are lacking on the effects of particle size on a consumption of total DM and NDF, and

\footnotetext{
* Supported by the National Dairy Key Technologies R \& D Programme for the 11th Five-Year Plan, Grant No. 2002BA518A17

${ }^{1}$ Corresponding author: e-mail: lisheng0677@vip.sina.com
} 
relatively few have been designed using dry cows. Lucerne hay is the most effective source affecting particle size of TMR for cows in China. For these reasons, the objective of the present study was to determine the effect of different particle size of lucerne hay on feed intake, chewing activity, rumen $\mathrm{pH}$ and fermentation in dry cows.

\section{MATERIAL AND METHODS}

\section{Design and treatments}

Three ruminally cannulated, multiparous dry cows averaging $700 \pm 50 \mathrm{~kg}$ BW were randomly assigned to one of $3 \times 3$ Latin square design. During each of the 21 -d periods, animals were offered one of three diets, which were chemically identical but differed in lucerne hay particle size (Table 1).

Table 1. Chemical composition of the diets (total mixed ration), \% of DM

\begin{tabular}{|c|c|c|c|c|c|}
\hline & \multicolumn{3}{|c|}{$\mathrm{TMR}^{1}$} & \multirow{2}{*}{ SEM } & \multirow{2}{*}{$\mathrm{P}$} \\
\hline & $\mathrm{SH}$ & $\mathrm{MH}$ & $\mathrm{LH}$ & & \\
\hline DM, \% & 40.75 & 41.17 & 39.96 & 0.42 & 0.07 \\
\hline $\mathrm{CP}$ & 13.10 & 12.97 & 13.07 & 0.3 & 0.30 \\
\hline NDF & 53.79 & 54.64 & 53.05 & 0.82 & 0.23 \\
\hline $\mathrm{ADF}$ & 34.85 & 35.04 & 34.69 & 0.31 & 0.15 \\
\hline Ash & 8.67 & 8.68 & 8.56 & 0.43 & 0.06 \\
\hline $\mathrm{Ca}$ & 0.57 & 0.55 & 0.56 & 0.02 & 0.25 \\
\hline $\mathrm{P}$ & 0.29 & 0.26 & 0.27 & 0.04 & 0.14 \\
\hline
\end{tabular}

${ }^{1} \mathrm{SH}$ - short lucerne hay, MH - medium lucerne hay, LH - long lucerne hay

The diets contained $13,2.05,2.2,1.75,0.1,0.2,0.2,0.2,0.2,40$ and $40 \%$ of DM maize, cottonseed meal, wheat bran, soyabean meal, limestone, dicalcium phosphate, sodium bicarbonate, salt, mineral and vitamin mix, lucerne hay and whole maize silage, respectively. Diets were composed of either short hay $(\mathrm{SH})$, medium $(\mathrm{MH})$ or long hay (LH). The length of lucerne was 2, 4 and $8 \mathrm{~cm}$, respectively, for $\mathrm{SH}, \mathrm{MH}$ and $\mathrm{LH}$. All diets were formulated to meet nutrient requirements of dry cows (NRC, 2001).

Animals were housed in individual stalls. Diets were fed as TMR for ad libitum consumption at 06.00 and $18.00 \mathrm{~h}$ to allow for approximately $5.0 \%$ refusal. Cows had free access to water.

\section{Experimental measures and sample analysis}

Samples of feed were collected twice weekly and orts were collected during the last $5 \mathrm{~d}$ of each period. Collected samples were analysed for crude ash, crude protein, NDF, ADF, calcium and phosphorus. The PSPS was used to measure 
particle size for both TMR and orts as described by Kononoff and Heinrichs (2003). Chewing activities of the three cows were monitored visually every 5 min for a 24-h period from the 12 to 13th day of the experimental period. Chewing activities were expressed as total minutes for the 24-h period or on the basis of DMI and NDF intake by dividing minutes of eating or ruminating by intake. On $\mathrm{d} 13$ of each period, ruminal contents were collected at an interval of 2 for $24 \mathrm{~h}$ daily. Rumen liquid $\mathrm{pH}$ was immediately determined using a handheld $\mathrm{pH}$ electrode (model M90, Corning Inc., Corning, NY). Ammonia and VFA concentrations were analysed using a phenol-hypochlorite assay (Broderick and Kang, 1980) and gas chromatography (Yang and Varga, 1989), respectively.

\section{Statistical analyses}

The experimental data were analysed as a $3 \times 3$ Latin square design using the Proc. Mixed, SAS (1998).

\section{RESULTS}

Compared with SH diet, proportion of DM and NDF on the first sieve significantly increased in the $\mathrm{MH}$ and $\mathrm{LH}$ diets $(\mathrm{P}<0.01)$, but the proportion of DM and NDF on the first sieve in LH diet increased slightly than the MH diet (Table 2). The proportion of DM on the second sieve was higher for the diet of

Table 2. Particle size distribution of experimental diets, DM retained on sieve, $\%$ and NDF

\begin{tabular}{|c|c|c|c|c|c|}
\hline \multirow{2}{*}{$\begin{array}{l}\text { Particle } \\
\text { size }\end{array}$} & \multicolumn{3}{|c|}{ Diets } & \multirow{2}{*}{ SEM } & \multirow{2}{*}{$\mathrm{P}$} \\
\hline & $\mathrm{SH}$ & $\mathrm{MH}$ & $\mathrm{LH}$ & & \\
\hline \multicolumn{6}{|l|}{ Dry matter, \% } \\
\hline$>19 \mathrm{~mm}$ & $50.39^{\mathrm{Bb}}$ & $65.04^{\mathrm{AaB}}$ & $66.32^{\mathrm{Aa}}$ & 1.07 & $<0.01$ \\
\hline $19-8 \mathrm{~mm}$ & $11.49^{\mathrm{B}}$ & $17.42^{\mathrm{A}}$ & $17.79^{\mathrm{A}}$ & 0.29 & $<0.01$ \\
\hline $8-1.18 \mathrm{~mm}$ & $27.88^{\mathrm{A}}$ & $12.02^{\mathrm{B}}$ & $11.85^{\mathrm{B}}$ & 0.39 & $<0.01$ \\
\hline$<1.18 \mathrm{~mm}$ & $10.23^{\mathrm{a}}$ & $5.53^{\mathrm{b}}$ & $4.05^{\mathrm{b}}$ & 1.25 & 0.04 \\
\hline \multicolumn{6}{|l|}{$N D F, \%$} \\
\hline$>19 \mathrm{~mm}$ & $54.83^{\mathrm{B}}$ & $67.18^{\mathrm{A}}$ & $67.24^{\mathrm{A}}$ & 0.31 & $<0.01$ \\
\hline $19-8 \mathrm{~mm}$ & 59.91 & 60.32 & 59.83 & 0.18 & 0.32 \\
\hline $8-1.18 \mathrm{~mm}$ & $52.68^{\mathrm{A}}$ & $44.27^{\mathrm{B}}$ & $39.66^{\mathrm{C}}$ & 0.23 & $<0.01$ \\
\hline$<1.18 \mathrm{~mm}$ & $47.37^{\mathrm{A}}$ & $43.94^{\mathrm{B}}$ & $37.88^{\mathrm{C}}$ & 0.17 & 0.01 \\
\hline peNDF ${ }^{1}, \% \mathrm{DM}$ & $47.51^{\mathrm{b}}$ & $51.62^{\mathrm{a}}$ & $50.90^{\mathrm{a}}$ & 1.38 & 0.03 \\
\hline
\end{tabular}

${ }_{a, b}$ means within a row with different superscripts differ $(\mathrm{P}<0.05),{ }^{\mathrm{A}, \mathrm{B}}(\mathrm{P}<0.01)$

${ }^{1}$ peNDF - proportion of DM retained on the 19- and 8-mm PSPS screens multiplied by dietary NDF content 
MH and LH than SH diet, but there was no significant difference in the proportion of NDF on the second sieve among the three diets $(\mathrm{P}>0.01)$. peNDF of the $\mathrm{MH}$ and LH diets were increased significantly compared to SH diet $(\mathrm{P}<0.05)$, but there was no significant difference between $\mathrm{MH}$ and $\mathrm{LH}$ diets.

In the MH and LH diets, DMI was reduced by 7.6 and $25.4 \%$, and NDF intake (NDFI) was reduced by 6 and 26.4\%, respectively, compared to SH diet (Table 3 ). Intake of peNDF (peNDFI) from cows fed LH diet was decreased significantly $(\mathrm{P}<0.01)$ compared the $\mathrm{SH}$ or $\mathrm{MH}$ diets.

Table 3. Feed intake and effects of increasing lucerne hay particle size on chewing activities

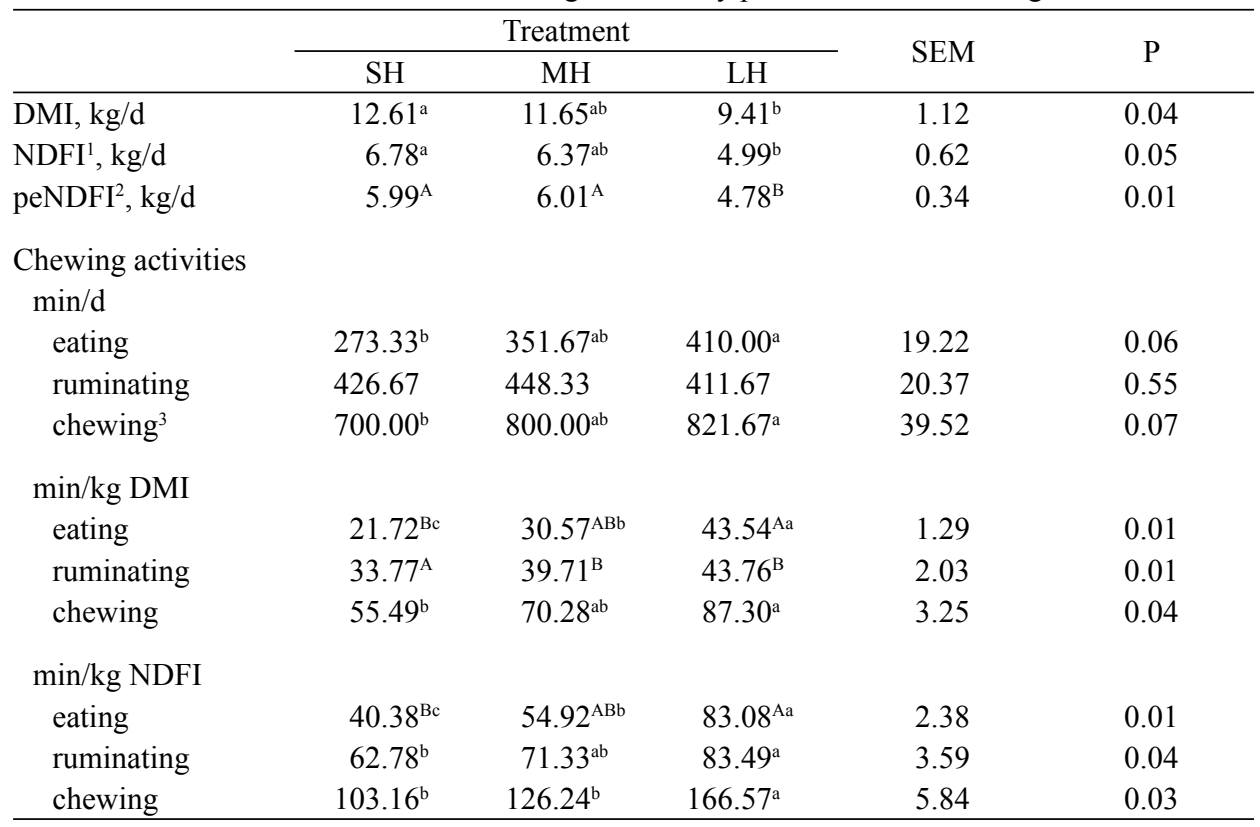

${ }^{1} \mathrm{NDFI}$ - intake of NDF; ${ }^{2}$ peNDFI - intake of physically effective NDF; ${ }^{3}$ chewing - min eating + min ruminating

The effects of lucerne hay particle size on eating and ruminating activity were presented in Table 3. Increasing the particle size did not obviously affect total ruminating time, but total eating time, ruminating time per unit of DM or NDF and eating time per unit of DM or NDF were increased significantly. As a result, daily total time of chewing (eating + ruminating) and chewing time per unit of DM or NDF intake increased with increasing particle size of the diets.

Rumen $\mathrm{pH}$ from cows fed $\mathrm{MH}$ and $\mathrm{LH}$ diet increased significantly $(\mathrm{P}<0.05)$ compared with cows fed SH diet (Table 4). Total concentration of VFA tended to decrease from 135.8 to $130.6 \mathrm{mM}$ with increasing particle size of the diets. Concentration of acetate, propionate and butyrate also decreased slightly with 
increasing particle size of the diets, but the ratio of acetate and propionate significantly increased with increasing particle size in the diets $(\mathrm{P}=0.05)$. Concentration of ammonia in the rumen increased by 10.4 and $19.3 \%$, respectively, when $\mathrm{MH}$ and $\mathrm{LH}$ diets were fed compared to SH.

Table 4. Parameters of rumen fermentation in cows fed experimental diets

\begin{tabular}{lccccc}
\hline & \multicolumn{3}{c}{ Treatment } & \multirow{2}{*}{ SEM } & \multirow{2}{*}{ P } \\
\cline { 2 - 4 } $\mathrm{pH}$ & \multicolumn{1}{c}{$\mathrm{SH}$} & $\mathrm{MH}$ & LH & & 0.04 \\
VFA, $m M / l$ & $6.20^{\mathrm{a}}$ & $6.45^{\mathrm{b}}$ & $6.37^{\mathrm{ab}}$ & 0.14 & \\
$\quad$ & & & & 0.04 \\
$\quad$ total & 135.87 & 132.57 & 130.67 & 1.72 & 0.30 \\
$\quad$ acetate (A) & $80.85^{\mathrm{a}}$ & $79.79^{\mathrm{b}}$ & $79.15^{\mathrm{b}}$ & 0.14 & 0.02 \\
$\quad$ propionate (P) & $30.44^{\mathrm{a}}$ & $29.12^{\mathrm{ab}}$ & $28.30^{\mathrm{b}}$ & 0.25 & 0.05 \\
$\quad$ butyrate & $14.17^{\mathrm{a}}$ & $13.66^{\mathrm{b}}$ & $13.39^{\mathrm{b}}$ & 0.08 & 0.04 \\
A/ P & $2.66^{\mathrm{b}}$ & $2.74^{\mathrm{a}}$ & $2.80^{\mathrm{a}}$ & 0.03 & 0.05 \\
Ammonia, mg/dl & $14.74^{\mathrm{a}}$ & $16.27^{\mathrm{ab}}$ & $17.59^{\mathrm{b}}$ & 0.37 & 0.05 \\
\hline
\end{tabular}

\section{DISCUSSION}

The results of our study showed that increasing hay particle size significantly decreased DMI, NDFI and peNDFI. It is possible that DMI was the most important factor affecting NDFI and peNDFI because of similar NDF and peNDF content among the three diets.

Reducing lucerne hay particle size was observed to result in a linear reduction in eating and ruminating time per unit of DM and NDF consumed. This result was similar to previous study (Kononoff and Heinrichs, 2003) which suggested increasing the proportion of particles $>19.0 \mathrm{~mm}$ may be a primary factor affecting chewing activity of dairy cattle. In the current study, reducing lucerne hay particle size did not significantly affect total ruminating time, but significantly reduced eating time, which was different from other reports (Bal and Shaver, 2000; Schwab and Shaver, 2002), it was possibly due to the greater differences of lucerne hay length. Present diets had the same sources and amount of NDF, and ingredients were same among different treatments. Therefore, the difference in lucerne hay particle size might be the most influential factor affecting chewing activity. Our study suggested that increasing the length of lucerne hay from 2 to $8 \mathrm{~cm}$ increased chewing activity. Some researchers (Yang and Beauchemin, 2006) reported it was likely that cows increased their chewing activity through either chewing rate or chewing time, or both, in relation to increased peNDF intake, but we didn't get similar result from a current study, increasing the proportion of particles $>8.0 \mathrm{~mm}$ may be a primary factor affecting chewing activity. 
In this study, increasing lucerne hay particle size increased rumen $\mathrm{pH}$ and decreased the concentration of acetate, propionate, butyrate and total VFA. Our results were consistent with the study of Kononoff and Heinrichs, (2003). The effect of particle size on total rumen VFA could be interpreted as that particle size affected the degree of rumen digestion of carbohydrates. Beauchemin and Rode (1997) reported that increasing fibre level and forage particle size effectively increased rumination, resulting in increased salivation, rumen $\mathrm{pH}$, acetate:propionate ratio. Concentration of rumen ammonia was increased with the increase in lucerne hay particle size, it may be the result that more ammonia produced in SH diet was used by microorganism because more VFA produced in rumen were available in $\mathrm{SH}$ diet.

\section{CONCLUSIONS}

The results of the study suggest that increasing particle size of lucerne hay can decrease dry matter and neutral detergent fibre intake. However, it can increase chewing behaviour of the animals, and the proportion of particles $>8.0 \mathrm{~mm}$ may be the primary factor that affect chewing activity.

\section{REFERENCES}

Bal M.A., Shaver R.D., 2000. Crop processing and chop length of corn silage: Effects on intake, digestion, and milk production by dairy cows. J. Dairy Sci. 83, 1264-1273

Beauchemin K.A., Rode L.M., 1997. Minimum versus optimum concentrations of fiber in dairy cow diets based on barley silage and concentrates of corn or barley. J. Dairy Sci. 80, 1629-1639

Broderick G.A., Kang J.H., 1980. Automated simultaneous determination of ammonia and total amino acids in ruminal fluid and in vitro media. J. Dairy Sci. 63, 64-75

Kononoff P.J., Heinrichs A.J., 2003. The effect of reducing alfalfa haylage particle size on cows in early lactation. J. Dairy Sci. 86, 1445-1457

Mertens D.R., 1997. Creating a system for meeting the fiber requirements of dairy cows. J. Dairy Sci. $80,1463-1481$

NRC, 2001. Nutrient Requirements of Dairy Cattle. National Research Council. 7th revised Edition. National Academy Sciences. Washington, DC

Schwab E.C., Shaver R.D., 2002. Processing and chop length effects in brown-midrib corn silage on intake, digestion, and milk production by dairy cows. J. Dairy Sci. 85, 613-623

Van Soest P.J., 1994. Nutritional Ecology of the Ruminant. 2nd Edition. Cornell University Press. Ithaca, NY, pp. 265-278

Yang C.M.J., Varga G.A., 1989. Effect of three concentrate feeding frequencies on rumen protozoa, rumen digesta kinetics, and milk yield in dairy cows. J. Dairy Sci. 72, 950-957

Yang W.Z., Beauchemin K.A., 2006. Effects of physically effective fiber on chewing activity and ruminal $\mathrm{pH}$ of dairy cows fed diets based on barley silage. J. Dairy Sci. 89, 217-228 